\title{
International
}

ORIGINAL ARTICLE

\section{BURNOUT AND TURNOVER EXPERIENCE: BEHIND THE NOBLE INTENTION IN PURSUING THE DIPLOMA OF NURSING PROGRAM IN A MALAYSIAN INSTITUTIONS OF HIGHER LEARNING}

Search engine:

www.ijmaes.org

\section{Hamidah H. ${ }^{1}$, Mazlinda M. ${ }^{2}$, Rosnah M. ${ }^{3}$, Azila T. ${ }^{4}$, Khadijah N@ Roslih. ${ }^{5}$,} Kelvin, J.M. ${ }^{6}$, Nurullzzatie M. ${ }^{7}$, Rohani M. ${ }^{8}$, Siti Fatimah S. $^{9}$

Author

$1,3,4,5,6,7,8,9$ Department of Nursing Faculty of Medicine \& Health Sciences, University, Sabah, Malaysia Coresponding Author

${ }^{2}$ Department of Medical Education, Faculty of Medicine \& Health Sciences, University ,Sabah, Malaysia, Email: mazlinda@ums.edu.my

\section{ABSTRACT}

Background: Burnout is defined as psychological syndrome experienced by an individual who is exposed to chronic stress which involved emotional, physical, and mental Exhaustion caused by prolonged excessive stress. As for students, going through the process of learning is a mounting complex stressful phenomenon that remained as the leading cause of poor academic performance and dropped out which sometimes may lead to psychological deviant or situation called depression. This study aimed to discover the causes of student nurses' Burnout and the intention to leave the program. Methodology: A cross-sectional survey of 127 nursing was selected based on Krejcie Morgan (1970) sample size calculation. Maslach Burnout Inventory (2016)to measure the burnout realm on emotional Exhaustion, Depersonalization and personal achievement. Twenty-two items with 7- points scale measuring responses of "Never (0)" to "Every day (7)" and three open-ended questions related to the intention of leaving the program. Results: Thirty-five( $35 \%)$ students had the feeling of dropping the program, and $52 \%$ had occurred during the first year of the study. Stress and financial struggles triggered the quitting as they felt the course had broken them down.Pursuing the program despite the glitches worth the fights, $99 \%$ of respondents acknowledged that this program is worth their future profession. Conclusion: They learnt to handle their emotional problem during work. Nursing as a field of knowledge of humanities has been able to transform the society who were insufficient in lives into good human beings.

Keywords: Burnout, turnover, nursing students, emotional exhausation, academic performance

Received on $4^{\text {th }}$ November 2020, Revised on $18^{\text {th }}$ November 2020, Accepted on $24^{\text {th }}$ November 2020 DOI:10.36678/IJMAES.2020.V06I04.004 


\section{INTRODUCTION}

Burnout is a state of emotional, physical, and mental respondents Exhaustion caused by excessive and prolonged stress. It occurs when ones feel overwhelmed, emotionally drained, and unable to meet constant demands.It is associated with feelings of hopelessness and difficulties in dealing with work or in doing the job effectively.' For students, studying and low academic performance can be the leading cause of burnout drop out, leading to a situation called a depression.

Burnout syndrome occurs morefrequently among a particular group of professions. It is increasingly recognized among healthcare professionals, and $\mathrm{HRQ}$ is estimating that Burnout may affect $10-70 \%$ of nurses and $30-$ $50 \%$ of physicians, nurse practitioners, and physician assistants which due to the demand interaction with people, work with human recipients of services. Apart from working environment with the public, individuals working in any othersdisciplines involvingwith extreme or hazardous responsibility, precision at the performance of duty, severe consequences, shift work, or tasks and responsibilities not liked, are at risk for development of burnout ${ }^{1,2}$.

Burnout, one of the six dimensions of distress, has many negative implications on both a personal and professional level. Professionally, Burnout can hinder job performance, for personally, Burnout affects character, relationships, and overall quality of life. Onethird of American nurses are reported with a burnout epidemic sweeping the country in particular with the emotional exhaustion score, of 27 or higher, which is considered to be "high burnout." Feelings of stress and anxiety, emotional detachment and chronic fatigue are all symptoms of Burnout that can have a significant impact on how nurses do their jobs. Nurse burnout will potentially impact the medical industry and Nurse Burnout, and it is a complex rising phenomenon related to stressful working environment $^{8,9}$.

What thought-provoking now is, Burnout not only experienced by trained nurses or medical profession, but it is also commonly affected the nursing students. Numerouscategory of literaturehad addressed these issues of burnout syndromes experienced by students in the classroom, worsteven in the clinical setting 3,4 .

A study on nursing degrees program studentswith highly competitive entrance examsfound that the nursing students who wish to obtain a nursing degree have similar exposures as denoted above. It has been widely accepted that burnout syndrome among the nursing students occurs as early as the training starts and the situation becoming intensified during the practical session ${ }^{13}$.

Tsang $\mathrm{L}$ said the major grievances of the nursing students are at the workplace ${ }^{18}$. It is where they begin to learn to transfer their classroom knowledge into practice. Factors such a; the environment of placement, the readiness of the clinical management to accept students' order, clinical teaching approach, clinical learning objectives, supervision and support system provided. Most ofthe nursing students experienced impolitenesskind of respect from the seniors and even the medical personnel in the clinical settings. The unfortunatestudents in the clinical areas 
exploited an avoiding approach in coping with a difficult problem to solve the Burnout ${ }^{5,6}$.

When students began to feel frustrated and issues that are not being addressed, the implications would be mainly on students themselves, the organizations and nursing profession. Theintention to leave the program or career is the significant implications by some of the nursing students as they experienced Exhaustion or disengagement due to stress to the academic and the clinical issues ${ }^{7}$. The purpose of this study is todeterminethe causes of Burnout among the nursing students, with a better understanding of the sourceswill improve the future training system.

Background of Study: This study was conducted in one of the nursing institutions in one of the public universities of Higher Learning in East Malaysia. The Nursing Department strives to excel the nursing graduates by providing the Nursing education based upon the principle of belief in God.

Three years of a full-time programaimed to produce nurses who are competent and caring through academic excellence training with holistic \& innovative nursing practice. Thus, the nursing students were nurtured to be progressive, disciplined, integrated as well as balanced in their intellectual, emotional, physical and spiritual outlook in the hope that those attributes will safeguard our students to be the well-being of society and worthwhile nations.

The total number of studentsin this study was 180 students, ranging from Year One till Year Three.Ninety per cent $(90 \%)$ of the students were female. The program was conducted based on the Malaysian Nursing Board guidelines. It has $50 \%$ theory and $50 \%$ practice

International Journal of Medical and Exercise Science |2020; 6 (4) with the credit hours of 90 credits for three years, and the full implementation is five years. The theory sessions were carried out on the main campus, and all practical training conducted using the facilities of the Malaysian Ministry of Health.

Almost $90 \%$ of the students in this study were localscomprises various ethnic groups, undertaking the nursing program. Most of the students coming into this program with pure intention and interest to assist the sicks. Somebelieved that, by submitting themselves into this field, they would be employed with a permanent job after three years of the rigorous training ${ }^{14,15}$.

\section{METHODOLOGY}

Study design: $A$ is a cross-sectional descriptive studyconducted on theDiploma of Nursing of Year One to Year Three students of the Department of Nursing Faculty of Medicine and Health Sciences, University Malaysia (UMS).

Sample/ Sampling Techniques: The total population was 184 nursing students comprised Year One, Two and Three. The sampling technique was based on Krejcie\& Morgan (1970)sampling size, and the required samplewas 127.

Selection of the was made through simple calculation; $184-127=54 / 3$ groups $=19$ students were excludedfrom each group, as formulatedin Table 1. Paper logsmarked with number 1 till all will draw number19. Those who received the marked records will be excluded from the study. 


\begin{tabular}{|c|c|c|}
\hline Year & Total & $\begin{array}{c}\text { Number of students } \\
\text { included in the study } \\
\text { number of Students }\end{array}$ \\
\hline Year 1 & $61-19$ & 42 \\
\hline Year 2 & $57-19$ & 48 \\
\hline Year 3 & $66-19$ & $\mathbf{1 2 7}$ \\
\hline
\end{tabular}

Table 1. Selection of Samplings

Instruments : The Instruments comprised two sections;Section A: Social demographic data and Section B: Maslach Burnout Syndrome
Inventory (MBI, 2016) with seven-score scale, ranging from 'never' to 'always' as characterized in Table 2.

\begin{tabular}{|c|c|c|c|c|}
\hline Domains & Items & \multicolumn{2}{|l|}{$\begin{array}{c}\text { Assessment } \\
\text { Scale of Burnout }\end{array}$} & $\begin{array}{l}\text { Determining the } \\
\text { Significance }\end{array}$ \\
\hline 1. Exhaustion & 7 & Never & 0 & Never \\
\hline 2. Depersonalization & 7 & A few times per year & 1 & $\begin{array}{c}\text { Or } \\
\text { Throughout }\end{array}$ \\
\hline $\begin{array}{ll}\text { 3. } & \text { Personal } \\
& \text { Achievement }\end{array}$ & 7 & Once a month & 2 & the year. \\
\hline \multirow{4}{*}{\multicolumn{2}{|c|}{$\begin{array}{c}\text { Maslach Burnout Syndrome } \\
\text { Inventory }\end{array}$}} & $\begin{array}{l}\text { A few times per } \\
\text { month }\end{array}$ & 3 & \\
\hline & & Once a week & 4 & \\
\hline & & A few times per week & 5 & \\
\hline & & Every day & 6 & \\
\hline
\end{tabular}

Table 2: Instrumentation Measuring Burnout

Data Collection process: This studywas commenced in September 2019 to December 2019 with a total participationof 127 nursing students as respondents. Sets of 22 structured questionnaires and three openended question- naires were uploaded into the system and arranged in accordance to year and group, ranging from Year 1 till Year 3. Selected students had been notified to respond to the questions uploaded. 
A timelinesystem was implemented to each group whereby the distribution of questionnaires was first done to Year One students, followed by Year Two and finally the Year Three students. Each group was given two weeks to respond to the same questionnaires. Every two weeks data was collected and sorted out into tables and analyzed-the whole data collection processes completed within six weeks.

\section{Data Analysis}

Returned questionnaires were checked for based on the research objectives, emphasizing on completeness, and data were analyzed through theaspectsburnout that transpired the students SPSS Version 22. Description of findings was during the course:

- Turnover: Intention ofleaving the Nursing Program

- Burnout: Due to Exhaustion, Depersonalization and Accomplishment

- $\quad$ Other reasons

The results were deliberated based on the following responses items;

- Never

- Over the year To organize the significance of results, the responses items were

- Over the monthwere summarized into two categories: Never Or Throughout the year.

- Over the week

\section{RESULTS}

\begin{tabular}{|c|c|c|c|}
\hline \multicolumn{2}{|c|}{ Family Income per month } & $\mathrm{N}=127$ & $100 \%$ \\
\hline \multicolumn{2}{|c|}{ Low income $(<\mathrm{RM} 3000)$} & 79 & $62.2 \%$ \\
\hline \multicolumn{2}{|c|}{ Middle income (RM3000-RM5000) } & 33 & $26.0 \%$ \\
\hline \multicolumn{2}{|c|}{ High income (>RM5000) } & 15 & $11.8 \%$ \\
\hline \multicolumn{2}{|r|}{ Total } & 127 & 100.0 \\
\hline \multicolumn{4}{|c|}{ Two Open-ended Questions } \\
\hline \multirow{2}{*}{ No } & Students' Statement & \multicolumn{2}{|c|}{$N=127(100)$} \\
\hline & & Yes & No \\
\hline 1 & $\begin{array}{l}\text { Have you ever felt like leaving this program } \\
\text { throughout your study }\end{array}$ & $\begin{array}{c}44 \\
(34.6 \%)\end{array}$ & $\begin{array}{c}83 \\
(65.4 \%)\end{array}$ \\
\hline
\end{tabular}




\begin{tabular}{|c|c|c|c|}
\hline \multirow[t]{4}{*}{2} & \multicolumn{3}{|c|}{ In what year of your study, you feel, I should leave this program. } \\
\hline & Year 1 & \multicolumn{2}{|c|}{$23(52.3 \%)$} \\
\hline & Year 2 & \multicolumn{2}{|c|}{$15(34.1 \%)$} \\
\hline & Year 3 & \multicolumn{2}{|c|}{$6(13.6 \%)$} \\
\hline \multicolumn{4}{|c|}{ Reasons for wanting to quit the nursing program } \\
\hline No & & \multicolumn{2}{|c|}{$N=44(100 \%)$} \\
\hline 1 & Stress due to family and financial problems & 25 & 56.8 \\
\hline 2 & Friends / relationship & 13 & 29.6 \\
\hline \multirow[t]{2}{*}{3} & Not Interested & 6 & $13.6 \%$ \\
\hline & Total & 44 & 100 \\
\hline
\end{tabular}

Table 3: Socio-demographic Data

\begin{tabular}{|c|c|c|c|c|}
\hline A & $\begin{array}{l}\text { STATEMENT ON } \\
\text { 'EXHAUSTION' }\end{array}$ & Score & $N=127$ & $100 \%$ \\
\hline \multirow{5}{*}{1} & \multirow{5}{*}{$\begin{array}{l}\text { I feel emotionally drained from my } \\
\text { study }\end{array}$} & Never & 13 & $10.2 \%$ \\
\hline & & Over the year & 42 & $33.1 \%$ \\
\hline & & $\begin{array}{l}\text { Over the } \\
\text { month }\end{array}$ & 46 & $36.3 \%$ \\
\hline & & Over the week & 26 & $20,4 \%$ \\
\hline & & Total & 127 & 100 \\
\hline \multirow[t]{5}{*}{2} & \multirow{5}{*}{$\begin{array}{l}\text { Working with people all day long } \\
\text { requires a great deal of effort }\end{array}$} & Never & 3 & $2.4 \%$ \\
\hline & & Over the year & 17 & $13.4 \%$ \\
\hline & & $\begin{array}{l}\text { Over the } \\
\text { month }\end{array}$ & 37 & $29.1 \%$ \\
\hline & & Over the week & 70 & $55.1 \%$ \\
\hline & & Total & 127 & 100 \\
\hline 3 & $\begin{array}{l}\text { I feel like my study is breaking me } \\
\text { down }\end{array}$ & Never & 3 & $2.4 \%$ \\
\hline \multicolumn{4}{|c|}{ International Journal of Medical and Exercise Science |2020; 6 (4) } & Page \\
\hline
\end{tabular}




\begin{tabular}{|c|c|c|c|c|}
\hline & & Over the year & 38 & $29.9 \%$ \\
\hline & & $\begin{array}{l}\text { Over the } \\
\text { month }\end{array}$ & 48 & $37.8 \%$ \\
\hline & & Over the week & 38 & $29.9 \%$ \\
\hline & & Total & 127 & 100 \\
\hline \multirow[t]{5}{*}{4} & \multirow[t]{5}{*}{ I feel frustrated by my studies } & Never & 20 & $15.6 \%$ \\
\hline & & Over the year & 36 & $28.3 \%$ \\
\hline & & $\begin{array}{l}\text { Over the } \\
\text { month }\end{array}$ & 37 & $29.1 \%$ \\
\hline & & Over the week & 34 & $27.0 \%$ \\
\hline & & Total & 127 & 100 \\
\hline \multirow[t]{5}{*}{5} & \multirow{5}{*}{$\begin{array}{l}\text { I feel I am working too hard for my } \\
\text { studies }\end{array}$} & Never & 13 & $10.2 \%$ \\
\hline & & Over the year & 24 & $18.9 \%$ \\
\hline & & $\begin{array}{l}\text { Over the } \\
\text { month }\end{array}$ & 41 & $32.3 \%$ \\
\hline & & Over the week & 49 & $38.6 \%$ \\
\hline & & Total & 127 & 100 \\
\hline \multirow[t]{5}{*}{6} & \multirow{5}{*}{$\begin{array}{l}\text { Interacting with people directly put too } \\
\text { much stress on me }\end{array}$} & Never & 29 & $10.2 \%$ \\
\hline & & Over the year & 40 & $31.5 \%$ \\
\hline & & $\begin{array}{l}\text { Over the } \\
\text { month }\end{array}$ & 34 & $26.7 \%$ \\
\hline & & Over the week & 24 & $19.9 \%$ \\
\hline & & Total & 127 & 100 \\
\hline \multirow[t]{5}{*}{7} & \multirow[t]{5}{*}{ I feel like I am at the end of my rope } & Never & 34 & $26.8 \%$ \\
\hline & & Over the year & 31 & $24.4 \%$ \\
\hline & & $\begin{array}{l}\text { Over the } \\
\text { month }\end{array}$ & 31 & $24.4 \%$ \\
\hline & & Over the week & 31 & $24.4 \%$ \\
\hline & & Total & 127 & 100 \\
\hline
\end{tabular}

Table 4: Exhaustion as acause of Burnout 


\begin{tabular}{|c|c|c|c|c|}
\hline B & $\begin{array}{c}\text { STATEMENT } \\
\text { ON 'DEPERSONALIZATION' }\end{array}$ & Score & $\mathrm{N}=127$ & $100 \%$ \\
\hline \multirow{5}{*}{1} & \multirow{5}{*}{$\begin{array}{l}\text { I feel I look after individual patients } \\
\text { and colleagues impersonally as if they } \\
\text { are objects }\end{array}$} & Never & 93 & $73.2 \%$ \\
\hline & & Over the year & 22 & $17.3 \%$ \\
\hline & & $\begin{array}{l}\text { Over the } \\
\text { month }\end{array}$ & 9 & $7.1 \%$ \\
\hline & & Over the week & 3 & $2.4 \%$ \\
\hline & & Total & 127 & 100 \\
\hline \multirow{5}{*}{2} & \multirow{5}{*}{$\begin{array}{l}\text { I feel tired when I get up in the } \\
\text { morning and have to face another day } \\
\text { at university or clinical posting }\end{array}$} & Never & 10 & $7.9 \%$ \\
\hline & & Over the year & 32 & $25.2 \%$ \\
\hline & & $\begin{array}{l}\text { Over the } \\
\text { month }\end{array}$ & 33 & $26.0 \%$ \\
\hline & & Over the week & 52 & $40.9 \%$ \\
\hline & & Total & 127 & $100 \%$ \\
\hline \multirow{5}{*}{3} & \multirow{5}{*}{$\begin{array}{l}\text { I have the impression that my } \\
\text { colleagues make me responsible for } \\
\text { some of their problems }\end{array}$} & Never & 24 & $18.9 \%$ \\
\hline & & Over the year & 41 & $32.3 \%$ \\
\hline & & $\begin{array}{l}\text { Over the } \\
\text { month }\end{array}$ & 36 & $28.3 \%$ \\
\hline & & Over the week & 26 & $20.4 \%$ \\
\hline & & Total & 127 & $100 \%$ \\
\hline \multirow{5}{*}{4} & \multirow{5}{*}{$\begin{array}{l}\text { I am at the end of my patience at the } \\
\text { end of my class or posting }\end{array}$} & Never & 50 & $39.4 \%$ \\
\hline & & Over the year & 29 & $22.8 \%$ \\
\hline & & $\begin{array}{l}\text { Over the } \\
\text { month }\end{array}$ & 25 & $19.7 \%$ \\
\hline & & Over the week & 23 & $18.1 \%$ \\
\hline & & Total & 127 & $100 \%$ \\
\hline \multirow{5}{*}{5} & \multirow{5}{*}{$\begin{array}{l}\text { I don't care about what happens to } \\
\text { some of my patients and colleagues }\end{array}$} & Never & 92 & $72.4 \%$ \\
\hline & & Over the year & 19 & $15.0 \%$ \\
\hline & & $\begin{array}{l}\text { Over the } \\
\text { month }\end{array}$ & 6 & $4.7 \%$ \\
\hline & & Over the week & 10 & $7.8 \%$ \\
\hline & & Total & 127 & $100 \%$ \\
\hline \multirow{5}{*}{6} & \multirow{5}{*}{$\begin{array}{l}\text { I have become more insensitive to } \\
\text { people since I've been studying }\end{array}$} & Never & 49 & $38.6 \%$ \\
\hline & & Over the year & 32 & $25.2 \%$ \\
\hline & & $\begin{array}{l}\text { Over the } \\
\text { month }\end{array}$ & 24 & $18.9 \%$ \\
\hline & & Over the week & 22 & $17.3 \%$ \\
\hline & & Total & 127 & $100 \%$ \\
\hline \multirow{5}{*}{7} & \multirow{5}{*}{$\begin{array}{l}\text { I am afraid that my study is making me } \\
\text { uncaring }\end{array}$} & Never & 59 & $46.5 \%$ \\
\hline & & Over the year & 27 & $21.3 \%$ \\
\hline & & $\begin{array}{l}\text { Over the } \\
\text { month }\end{array}$ & 24 & $18.8 \%$ \\
\hline & & Over the week & 17 & $13.4 \%$ \\
\hline & & Total & 127 & $100 \%$ \\
\hline
\end{tabular}

Table 5: Depersonalizationas a cause of burnout 


\begin{tabular}{|c|c|c|c|c|}
\hline C & $\begin{array}{c}\text { STATEMENT } \\
\text { ON ‘ACCOMPLISHMENT’ }\end{array}$ & Score & $\mathrm{N}=127$ & $100 \%$ \\
\hline \multirow[t]{5}{*}{1} & \multirow{5}{*}{$\begin{array}{l}\text { I accomplished many worthwhile things } \\
\text { in my studies }\end{array}$} & Never & 1 & $0.8 \%$ \\
\hline & & Over the year & 9 & $7.8 \%$ \\
\hline & & Over the month & 42 & $33.0 \%$ \\
\hline & & Over the week & 75 & $59.1 \%$ \\
\hline & & Total & 127 & 100 \\
\hline \multirow[t]{5}{*}{2} & \multirow[t]{5}{*}{ I feel full of energy } & Never & 2 & $1.6 \%$ \\
\hline & & Over the year & 15 & $11.8 \%$ \\
\hline & & Over the month & 34 & $26.8 \%$ \\
\hline & & Over the week & 76 & $58.9 \%$ \\
\hline & & Total & 127 & $100 \%$ \\
\hline \multirow[t]{5}{*}{3} & \multirow{5}{*}{$\begin{array}{l}\text { I am easily able to understand what my } \\
\text { patients and colleagues feel }\end{array}$} & Never & 1 & $0.8 \%$ \\
\hline & & Over the year & 7 & $5.5 \%$ \\
\hline & & Over the month & 20 & $15.7 \%$ \\
\hline & & Over the week & 99 & $78 \%$ \\
\hline & & Total & 127 & $100 \%$ \\
\hline \multirow[t]{5}{*}{4} & \multirow{5}{*}{$\begin{array}{l}\text { I look after my patients and colleagues } \\
\text { problems very effectively }\end{array}$} & Never & 2 & $1.6 \%$ \\
\hline & & Over the year & 4 & $3.1 \%$ \\
\hline & & Over the month & 28 & $22.1 \%$ \\
\hline & & Over the week & 93 & $73.2 \%$ \\
\hline & & Total & 127 & $100 \%$ \\
\hline \multirow[t]{5}{*}{5} & \multirow{5}{*}{$\begin{array}{l}\text { In my work, I handle my emotional } \\
\text { problems very calmly }\end{array}$} & Never & 2 & $1.6 \%$ \\
\hline & & Over the year & 6 & $4.7 \%$ \\
\hline & & Over the month & 28 & $22.1 \%$ \\
\hline & & Over the week & 91 & $71.6 \%$ \\
\hline & & Total & 127 & $100 \%$ \\
\hline \multirow[t]{5}{*}{6} & \multirow{5}{*}{$\begin{array}{l}\text { Through my work, I feel that I have a } \\
\text { positive influence on people }\end{array}$} & Never & 2 & 1.6 \\
\hline & & Over the year & 11 & $7.4 \%$ \\
\hline & & Over the month & 39 & $30.7 \%$ \\
\hline & & Over the week & 76 & $59.8 \%$ \\
\hline & & Total & 127 & $100 \%$ \\
\hline \multirow[t]{5}{*}{7} & \multirow{5}{*}{$\begin{array}{l}\text { lam easily able to create a relaxed } \\
\text { atmosphere with my patients and } \\
\text { colleagues }\end{array}$} & Never & 0 & $0 \%$ \\
\hline & & Over the year & 9 & $7.1 \%$ \\
\hline & & Over the month & 29 & $22.9 \%$ \\
\hline & & Over the week & 89 & $70.0 \%$ \\
\hline & & Total & 127 & $100 \%$ \\
\hline \multirow[t]{5}{*}{8} & \multirow{5}{*}{$\begin{array}{l}\text { I feel refreshed when I have been } \\
\text { closed to my colleagues in the class }\end{array}$} & Never & 2 & 1.6 \\
\hline & & Over the year & 7 & 5.6 \\
\hline & & Over the month & 26 & 20.4 \\
\hline & & Over the week & 92 & 72.4 \\
\hline & & Total & 127 & $100 \%$ \\
\hline
\end{tabular}

Table 6: Accomplishment as a cause of Burnout 


\section{DISCUSSION}

Burnout situation experienced by the nursing student was measured through the overall measurement of whether they have experienced it Throughout the yearor Never experienced such a situation. The weighing up of the results was done on three causes of Burnout, namely, Exhaustion, Depersonalization and Accomplishment ${ }^{11}$.

The first analysis of the study was the information on Turnover. Turnover in this study means, students intend to leave the diploma in Nursing program. The results were obtained through 2 open-ended questions. We found that $65.40 \%$ of nursing students had the intention to leave the program that transpired them throughout the years of study and $62.0 \%$ were from the low-income families with an income of less than RM 3000 per month. This group is quite precisely that ourproclamation from the findings envisaged that it is this group of students that is most likely to experience more stress and Burnout. Student nurses that participated in the threat of financial hardship can lead to less study time with more personal focus and lead to worsening the adverse outcomes $^{10}$. With all the above difficulties mentioned, it is understandable students may start to feel uncomfortable with their choice of studies.

The percentage of students who wanted to leave this program was quite obvious, as students went the higher level, of course, the desire to leave the program decreases to approximately $50 \%$. The study showed the first year of study was $57 \%$ of students wanted to go, followed by $30 \%$ in the second year and $14 \%$ in the third year. Principal reasons for leaving the program were an academic failure, family or personal difficulties, and wrong career choice ${ }^{12}$. However, academic failure was no single contributing factor that was thought to make students leave. There are factors such as communication and operational aspects between the university and clinical areas, feelings of not being valued, unmet expectations resulted in student nurses to leave. They also expressed that these factors were of concern to students and appeared to have a cumulative effect that led them to question whether they should continue their education programme.

We found that there is a unique outcome when a comparison of Turnover of this study with a study conducted on trained nurses with the same motive - intending to leave. The comparison of results showed that the longer the nurses in the workplace, the high percentage of them wanting to leave the job. Recruiting \& retaining new nurse grads, the new nurse grad turnover rates are roughly $30 \%$ in the first year of practice, and as high as $57 \%$ in the second year ${ }^{9,10}$.

The new nurses reported that low job satisfaction associated with heavy workloads, disappointment about scheduling, insufficient time with patients, absence of independent practice, and the lack of intrinsic and extrinsic workplace rewards. Poor relationships with peers, managers, and interprofessional colleagues also lead to dissatisfaction. However, most nurses leave their jobs for many reasons, both voluntary, desire for change or promotion, job dissatisfaction, geographical move, returning to school or leaving the nursing profession for good.

For the analysis on Exhaustion, the results had shown that $98 \%$ of students claimed they were too exhausted and this makes them feel as if they were breaking down and working with 
people all day long demanded a great deal of effort especially in the clinical areas. Although as student nurses do not hold the same level of responsibility as qualified staff of heavy workload, having student status is stressful in itself ${ }^{13}$. Perhaps that could be the first sign, and the highest predictor of Burnout is emotional Exhaustion. Most nurses know what it is like to be tired, but emotional Exhaustion leaves the feeling wholly drained as a result of the stress of the job. It added, among students also, they did not show the burnout syndrome. However, they showed high scores on Emotional Exhaustion factors, which may add up to an early indicator of the development of the burnout process and Exhaustion ${ }^{15}$.

As we know, moststudent nurses spend half of their programme experience in clinical areas, and it is these placement experiences that caused a massive amount of stress, which sometimes can lead to students discontinuing their programme of study. The initialclinical experience was said to be very stressful, and they experienced more anxiety compared with third and fourth-year students. The fear of working with people all day long requires a great deal of effort, fearof harming patients, the sense of not belonging to the nursing team and of not being fully competent on registration were mentioned as causes of burnout

They also faced the harsh realities of autonomous university life, the difficulties of transitioning in the basic nursing sciences and the daily dilemmas of dealing with critically-ill patients during their routine clinical placements ${ }^{13}$.The clinical posts require them to practice full shift hours for about 6 to 8 weeks, and in specific nursing colleges, students don't see the long holidays as other students do. Due to the hectic schedule, their input into student life is minimal, which often find nursing students have forgotten by universities, Byrne, G \& RuffoniS (2016) ${ }^{2}$.

The feeling of Exhaustion, due to their study, made them, especially the new ones began to spend less time at home with family as they start to run shifts during their student's life. With all the above difficulties mentioned, it is understandable that some of these students may begin to feel uncomfortable with their choice of studies especially if they have the feeling of not coping with the environment and hardiness to survive the coursework. Such sentiments could quickly bring about further an already deadly academic background, which could easily lead to them becoming burnt out ${ }^{17}$.

The second element of the course of Burnout among the nursing students was Depersonalization. Generally, the word depersonalization is defined as "unfeeling or impersonal response toward recipients of one's service, care, treatment, or instruction. For example,a nurse experiencing Depersonalization might not be able to be as empathetic or caring toward a patient dealing with treatment, and this is how Burnout happened. The nurses' attitude towards patients may be harmful or even heartless or unfeeling and sometimes articulating in unprofessional comments directed at colleagues, feeling nothing when a patient dies, or even blaming patients for their problems. In the case of Depersonalization, it is reported that when ones become so exhausted, they tend to detach themselves from their surroundings. Their outlook may be harmful or even calloused, and it can express itself in unprofessional comments directed at colleagues, feeling nothing when a patient dies, or even blaming patients for their problems.In 
this study, 117 (92.1\%) students felt very tired in the morning to face another day at university or in clinical posting and followed by 103 (81.9\%) had the impression their colleagues made them responsible for their problems, and this happened throughout the learning year.The feeling of fatigue in every way, people who are emotionally exhausted often feel like they have lost control of their lives they often reported feeling trapped in their situation, whether it is at work or in an outside relationship. This study also has shown that over $50 \%$ of students claimed that they were at the end of their classes or clinical posting; they also have become more insensitive to people since they were studying. They were afraidthat the study was making them uncaring ${ }^{16}$.

Nursing students cope with stress in a variety of ways, and many of their coping mechanisms were constructive. However, one of the most common coping mechanisms for the pressures of nursing school leads directly to Burnout: avoidance coping.Avoiding problems is easy. Putting off assignments, leaving things for later, or assuming the future self will take care of everything is easy. Avoidance of coping is the strongest predictor of Burnout in nursing students. By avoiding problems, students just add to the pile of issues that can potentially leave them in states of distress. What is impressive in this case was, even though students claimed they were too tired and their friends added to the problems, they still respected their friends and patients they cared for and did not consider them asthe objects. By focusing on the positive outcomes will make us think deep, meaningful motivations, and this helps us insustainingthrough difficult times. The sincere caregiving attitude will make us stronger if we are looking for the silver lining in our career future. The final significant predictor of Burnout is a reduced feeling of Personal Accomplishment. You may not feel that you're a good nurse or that you make any difference at all in patients' lives. Nurses working in highintensity settings, like the ICU or emergency room, may experience this more often as they receive a more significant proportion of cases where little can be done for the patient ${ }^{14}$.

Accomplishment is the last course of Burnout in this study. It has eight elementson intended achievement, and the emphasis was on relationships with peers, the training environment and contentment with the program. Almost all eight aspects received 98.4\% excellence. The highest Accomplishment obtained in this study was, the gratitude from students (100\%) that they were able to create a calm atmosphere among patients and friends. Almost all the eight elements found in the aspect of Accomplishment received 98.4\% excellence. The highest Accomplishment obtained in this study was, the gratitude from students (100\%) that they were able to create a calm atmosphere among patients and friends.

Those findings on the course of Accomplishment were very encouraging. If we look in detail, Nursing Education is education about nobility. Therefore, it was evident that the results of the Accomplishment received $100 \%$ gratitude from students. The very basic concepts of Nursing education isabout humanity and preserving safety and professionalism. As for the qualified nurses, they also enrol in continuing education courses that help them gain more profound knowledge of their profession and become better nurses. They do not spend their entire workday locked away and isolated in an office. They work while surrounded by both colleagues and patients, meeting new people each day. They encounter all 
sorts of individuals, like newborn babies, teenagers with severe illnesses and unique perspectives on life, and elderly patients with end-of-life wisdom, StaffWriters (2020).

Ethical Clearance: The study has approval obtained from the UMS FMHS Research Ethical committee, ref no: UMS/FPSK/6.9/100-6/1/97

Conflicts of Interest: There is no conflict of interest in this study.

Fund for the study: This is self-funded study.

\section{CONCLUSION}

Burnout experienced due to Exhaustion, 98\% of students claimed that they were too exhausted and were flouting down due to the study and working with people all day long demanded a great deal of effort. As for Depersonalization, $92.1 \%$ of students felt very tired in the morning to face other days of clinical posting. However, for the Accomplishment, the highest achievement, $100 \%$ of students expressed their gratefulness that they were able to create a calm atmosphere among patients and friends. They were pursuing the program despite the hardships and Burnout due to study, worth the journey.

Students in this study(62\%) appeared from low-income families when asked if they had ever felt like leaving the program, $65.4 \%$ said 'No'. The reluctant to leave the program could be students from the low-income group despite the hardship in life as well as in the study, and they were able to hold on and successfully demonstrated good attitudes to be a nurse. The Nursing institutions of this study is capable of transforminga deprived societyinto good being. To students, pursuing the program despite the glitches worth the fights for upcoming career.

\section{REFERENCES}

1. Bridgeman, P.J., Bridgemen, B.M., \&Baroneomin, J (2018). Burnout syndrome among healthcare professionals. American Journal of Health-System Pharmacy, 3(75),147-152.

2. Morales E. Lived experience of Hispanic new graduate nurses-a qualitative study. Journal of Clinical Nursing. 2014; 23(9-10): 1292-1299

3. Doulougeri, K., Georganta, K., \& Montgomery, A. (2016). "Diagnosing" Burnout among healthcare professional: Can we find consensus? Cogent Medicine, $3(1), 1$.

4. Flinkman, M., Bouret, I.U.,\&Salanterä, S. (2013). Young Registered Nurses' Intention to Leave the Profession and Professional Turnover in Early Career: A Qualitative Case Study. Hindawi, 2013.1-12.

5. Hamidah, H., Maziah, M., Ayesha, B., Subahan, T., \&SitiRahayah, A. (2012). The Development of a Malaysian Model Internship Programme (MyMIP): A Preceptor Model for Nurses in their Early Stage of Profession. Procedia-Social and behavioural sciences, 64(2012),492-500.

6. Hong, YK., Kim, YH., \&Son, H. (2016). Effect of Nurses' Incivility Experienced by Nursing Student, Coping. Journal of Korean Acad Nurs Adm, 4(23), 323-331.

7. Kantek, F. (2010). Why do student nurses leave? Procedia Social and behavioural sciences, 9(2010).1922-1925.

8. Law B, Chan E. The experience of learning to speak up: A narrative inquiry on newly graduated registered nurses. Journal of Clinical Nursing. 2015; 24(13-14): 18371848.

9. Tsang L, Sham S, Law S, et al. ToUCH Program on competence, occupational stress and self-efficacy of newly graduated registered nurses in United Christian Hospital: A mixed method research study. 
Journal of Nursing Education and Practice. 2016; 6(8; 129-137

10. Krejcie, V.R., \& Morgan, W.D. (1970). Determining Sample Size for Research Activities. Education and psychological measure, 30(3); 607-610.

11. Parker V, Giles M, Lantry G, et al. New graduate nurses' experiences in their first year of practice. Nurse Education Today. 2014; 34(1; 150-156.

12. Mathias, T.C., \& Wentzel, D. (2017). A descriptive study of Burnout, compassion fatigue and compassion satisfaction in undergraduate nursing students at a tertiary education institution in KwaZuluNatal. Curators, 40(1); a1784.

13. Njim, T., Mbanga, C., Mouemba, D., Makebe, H., Toukam, L., Kika, B., \& Mulango, I. (2018). Determinants of burnout syndrome among nursing students in Cameroon: a cross-sectional study. BMC Research Notes, 11(450); 1-6.

14. Ebrahimi $H$, Hassankhani $H$, Negarandeh $R$, et al. Barriers to support for new graduated nurses in clinical settings: A qualitative study. Nurse Education Today. 2016; 37: 184-188.
15. Lea J, Cruickshank M. Supporting new graduate nurses making the transition to rural nursing practice: Views from experienced rural nurses. Journal of Clinical Nursing. 2015; 24(19-20); 2826-2834.

16. Stimpfel, A.M., Sloane, D. M., \& Aiken, L.A (2020). Higher The Levels Of Burnout And Patient Dissatisfaction. Health Affairs, 31(110); 2501-92509.

17. Tomaschewski, B., Lunardi, L.V., Lunardi, L.G., Barlem, E., Silveirs, R., \&Vidal, D. (2014). Burnout syndrome among undergraduate nursing students at a public university. Rev. Latino-Am. Enfermagem, 22(6); 934-41.

18. Tsang L, Sham S, Law S, et al. ToUCH Program on competence, occupational stress and self-efficacy of newly graduated registered nurses in United Christian Hospital: A mixed method research study. Journal of Nursing Education and Practice. 2016; 6(8); 129-137.

\section{Citation:}

Hamidah H., Mazlinda M., Rosnah M., Azila T., et al. (2020). Burnout and turnover experience: Behind the noble intention in pursuing the diploma of nursing program in a Malaysian institutions of higher learning, ijmaes; 6 (4); 869-882. 